\title{
Effect of RF Magnetron Sputtered Nickel Oxide Thin Films as an Anode Buffer Layer in a $\mathrm{P}_{3} \mathrm{HT}$ :PCBM Bulk Hetero-Junction Solar Cells
}

\begin{abstract}
JWAYEON KIM ${ }^{a, *}$, YONGKYU KO ${ }^{a}$ AND KYEONGSOON PARK ${ }^{b}$
${ }^{a}$ Department of Materials Engineering, Hoseo University, Asan, Chungnam 336-795, Republic of Korea

${ }^{b}$ Faculty of Nanotechnology and Advanced Materials, Sejong University, Seoul 143-747, Republic of Korea

Bulk heterojunction solar cells were investigated using poly(3-hexylthiophene) $\left(\mathrm{P}_{3} \mathrm{HT}\right):[6,6]$-phenyl- $\mathrm{C}_{61}$ butyric acid methyl ester (PCBM) with a nickel oxide (NiO) anode buffer layer between the photoactive layer and an indium tin oxide (ITO) anode layer. The $\mathrm{NiO}$ anode buffer layer was deposited using radio frequency magnetron sputtering on an ITO electrode layer for effective hole transport and electron blocking. The NiO film is a $p$-type semiconductor with resistivity of $0.35 \Omega \mathrm{cm}$. The power conversion efficiency was improved substantially by the NiO anode buffer layer compared to a solar cell with an anode buffer layer made from poly(3,4-ethylenedioxythiophene) (PEDOT):poly(styrene sulfonate) (PSS). The solar cell with a $10 \mathrm{~nm}$ thick NiO anode buffer layer had a power conversion efficiency of $4.71 \%$. These results are explained by the improved charge transport across the interface between the active layer and ITO electrode.
\end{abstract}

DOI: 10.12693/APhysPolA.133.887

PACS/topics: $\mathrm{P}_{3} \mathrm{HT}$ :PCBM bulk heterojunction solar cell NiO anode buffer layer, PEDOT:PSS anode buffer layer

\section{Introduction}

Bulk heterojunction (BHJ) solar cells based on organic materials are very attractive because of their low cost, large area, and light weight $[1,2]$. For effective hole transport and electron blocking, PEDOT:PSS has commonly been used as an anode buffer layer (ABL) between an active layer of PCBM and an ITO electrode. However, PEDOT:PSS has problem with causing corrosion to the ITO, as well as non-uniform morphology and instability $[3,4]$. Kawano et al. reported that PEDOT:PSS rapidly degrades the performance of a solar cell because of corrosion of the ITO anode electrode from the absorption of humidity in the air [5]. Therefore, it is necessary to develop a new ABL to replace the PEDOT:PSS in $\mathrm{P}_{3} \mathrm{HT}$ :PCBM BHJ solar cells.

Suitable ABL materials should have sufficient optical transparency in the visible spectral region. They should also effectively transport holes and block electrons to the anode in a $\mathrm{P}_{3} \mathrm{HT}$ :PCBM BHJ solar cell because $\mathrm{P}_{3} \mathrm{HT}$ and $\mathrm{PCBM}$ are in direct contact with both electrodes. To achieve this, the conduction band energy $\left(E_{c}\right)$ level of the ABL materials (which have $p$-type semiconductors) should be sufficiently higher than the lowest unoccupied molecular orbital (LUMO) energy level of the PCBM for electron protection. Furthermore, the valence band energy $\left(E_{v}\right)$ level should be near the highest occupied molecular orbital (HOMO) energy of $\mathrm{P}_{3} \mathrm{HT}$ for hole transport. There should also be ohmic contact at the interface between the $\mathrm{P}_{3} \mathrm{HT}$ and $\mathrm{ABL}[6,7]$.

\footnotetext{
* corresponding author
}

$\mathrm{NiO}$ thin film has received considerable attention recently as a replacement for the PSS:PEDOT ABL in a $\mathrm{P}_{3} \mathrm{HT}$ :PCBM BHJ solar cell $\mathrm{NiO}$ is a $p$-type transparent semiconductor with an $E_{v}$ level of $-5.4 \mathrm{eV}$ and $E_{c}$ level of $-1.8 \mathrm{eV}$. These properties result in effective hole transport and electron blocking [8]. Furthermore, $\mathrm{NiO}$ forms ohmic contact with $\mathrm{P}_{3} \mathrm{HT}$.

In the present study, we investigated the effect of a $\mathrm{NiO}$ ABL in a $\mathrm{P}_{3} \mathrm{HT}$ :PCBM BHJ solar cell. A thin film of $\mathrm{NiO}$ was deposited by radio frequency (RF) magnetron sputtering. This method can be used to deposit films on a large area with good adhesion, high deposition, good thickness uniformity and high density [9]. The electrical and optical properties of the $\mathrm{NiO}$ film are strongly affected by the sputtering conditions, such as the $\mathrm{Ar}: \mathrm{O}_{2}$ gas flow ratios and thermal annealing temperatures.

\section{Experimental}

Corning glass (\#1737) substrates were first cleaned using sequential ultrasonic baths in acetone, ethanol, and deionized water, followed by drying with an $\mathrm{N}_{2}$ gun. Presputtering was carried out for $5 \mathrm{~min}$ to eliminate contaminants on the target before deposition of the films. $\mathrm{NiO}$ films $(80 \mathrm{~nm})$ were then deposited on the substrates using $\mathrm{RF}$ magnetron sputtering (RF power: $100 \mathrm{~W}$, distance between target and substrate: $10 \mathrm{~cm}$, pressure: $10^{-3}$ Torr, total gas flow rate: $100 \mathrm{sccm}$ ). The deposition was carried out using a target with a diameter of 2 in and various $\mathrm{Ar}: \mathrm{O}_{2}$ gas flow ratios (60:40, 50:50, 40:60, and 30:70) at room temperature in order to obtain optimal $\mathrm{NiO}$ films. The films were also deposited with a gas ratio of 30:70 and thermally annealed at 50, 100,150 , and $200^{\circ} \mathrm{C}$ at low pressure $\left(10^{-3}\right.$ Torr, $\mathrm{O}_{2}$ gas 
flow: $100 \mathrm{sccm}$ ) to improve the properties. The electrical properties of the films were then measured, including the resistivity, carrier concentration, and the Hall mobility using the Van der Pauw method at room temperature (Ecopia, HMS-3000). The optical transmittance of $10 \mathrm{~nm}$ $\mathrm{NiO}$ film was measured using a UV-Vis spectrophotometer (Perkin Elmer, Lambda-950) in the range of 300$800 \mathrm{~nm}$. UV photoelectron spectroscopy (UPS) was used to measure $E_{v}$ level, the Fermi energy $\left(E_{f}\right)$ level, and the energy gap $\left(E_{g}\right)$ of $\mathrm{NiO}$ films deposited using $\mathrm{Ar}: \mathrm{O}_{2}$ gas flow ratios of 50:50 and 30:70 (UPS: $\mathrm{He}(\mathrm{I})$ photon energy: $21.2 \mathrm{eV}$, Sigma Probe, Thermo VG Scientific).

Solar cells were fabricated on ITO glass $(10 \Omega / \mathrm{sq})$ that had been cleaned by sequential ultrasonic baths in acetone, ethanol, and deionized water, followed by drying with an $\mathrm{N}_{2}$ gun. Different $\mathrm{NiO}$ ABLs with thicknesses of 5,10 , and $15 \mathrm{~nm}$ were deposited on the ITO glass using $\mathrm{RF}$ magnetron sputtering with an $\mathrm{Ar}: \mathrm{O}_{2}$ gas flow ratio of 30:70 at room temperature. Thermal annealing was then performed at $200{ }^{\circ} \mathrm{C}$ for $10 \mathrm{~min}$ in low pressure $\left(10^{-3}\right.$ Torr, $\mathrm{O}_{2}$ gas flow: $\left.100 \mathrm{sccm}\right)$. A PEDOT:PSS ABL was spin coated with a thickness of $100 \mathrm{~nm}$ on a different ITO glass substrate, and dried in an oven and exposed to UV ozone for $3 \mathrm{~min}$. The photoactive layers were deposited with thicknesses of $100 \mathrm{~nm}$ by spin coating in a glove box and annealed at $140^{\circ} \mathrm{C}$ for $20 \mathrm{~min}$ on a hot plate under $\mathrm{N}_{2}$ atmosphere. Then, blended solutions of $\mathrm{P}_{3} \mathrm{HT}$ (Sigma-Aldrich):PCBM (Sigma-Aldrich) were prepared in 1,2-dichlorobenzene with a 1:1 mass ratio of $\mathrm{P}_{3} \mathrm{HT}$ and PCBM (each $20 \mathrm{mg} / \mathrm{ml}$ ). The solutions were stirred overnight at $60^{\circ} \mathrm{C}$. Finally, Al cathodes $(100 \mathrm{~nm})$ were deposited by thermal evaporation and then thermally annealed for $20 \mathrm{~min}$ at $150^{\circ} \mathrm{C}$. The area of the active layer was $0.04 \mathrm{~cm}^{2}$. The electrical properties of the solar cells were measured under $100 \mathrm{~mW} / \mathrm{cm}^{2}$ of illumination (AM 1.5) using a solar cell analyzer (Spectra-Nova Technologies) installed with a xenon lamp. The light intensity of the UV lamp was calibrated using a standard Si photodiode detector.

\section{Results and discussion}

\subsection{Electrical and optical properties of NiO films}

The electrical properties of the $\mathrm{NiO}$ films $(80 \mathrm{~nm})$ deposited at room temperature were measured as a function of the $\mathrm{Ar}: \mathrm{O}_{2}$ gas flow ratio. As the $\mathrm{Ar}: \mathrm{O}_{2}$ gas flow ratios increased, the resistivity and Hall mobility of the films gradually decreased and the carrier concentration of $\mathrm{NiO}$ films gradually increased, as shown in Fig. 1. The resistivity of the film deposited with a ratio of 30:70 was $0.95 \Omega \mathrm{cm}$, which was the lowest value among the samples tested. As the partial oxygen pressure used in the deposition increases, the number of nickel vacancies should increase, and $\mathrm{NiO}^{2+}$ is substituted by $\mathrm{Ni}^{3+}$ in order to maintain the electro-neutrality, which resulted in a highly doped $p$-type semiconductor [10].

To decrease the resistivity and increase the transmittance of $\mathrm{NiO}$ films deposited with an $\mathrm{Ar}: \mathrm{O}_{2}$ flow ratio

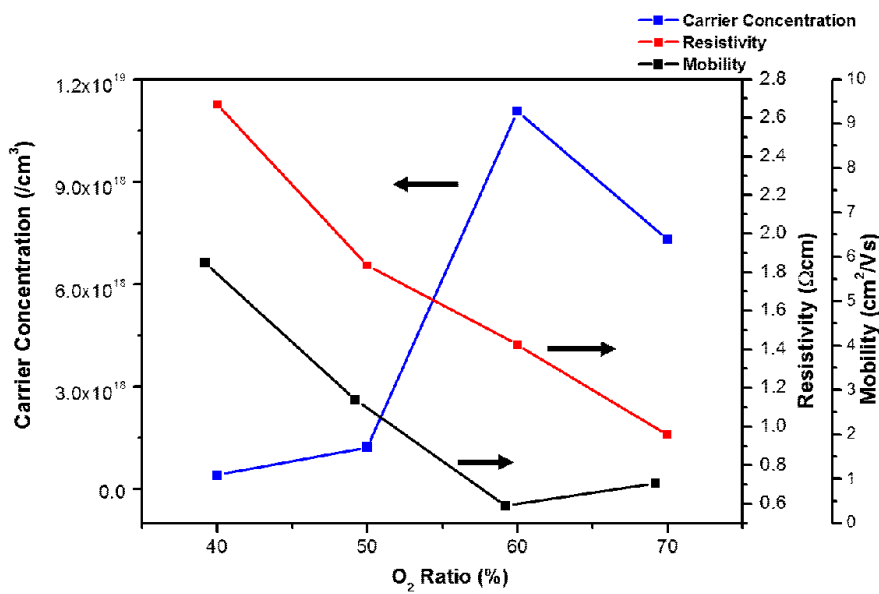

Fig. 1. Electrical properties of $80 \mathrm{~nm} \mathrm{NiO}$ films deposited at room temperature with different Ar: $\mathrm{O}_{2}$ gas flow ratios.

of 30:70, thermal annealing was carried out for $10 \mathrm{~min}$ at 50,100 , and $200^{\circ} \mathrm{C}$ at low pressure $\left(10^{-3}\right.$ Torr, $\mathrm{O}_{2}$ gas flow ratio: $100 \mathrm{sccm})$. As the annealing temperature increased, the resistivity and Hall mobility of the $\mathrm{NiO}$ films gradually decreased, while the carrier concentration gradually increased, as shown in Fig. 2. The resistivity obtained with annealing at $200^{\circ} \mathrm{C}$ was $0.35 \Omega \mathrm{cm}$, which was the lowest value among the tested samples. These process conditions were the best for the $\mathrm{NiO}$ deposition in this experiment.

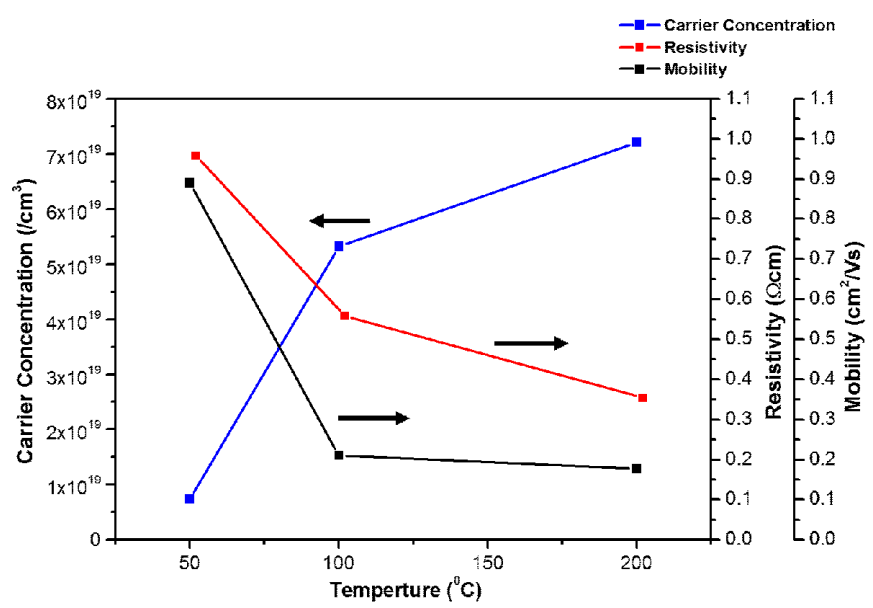

Fig. 2. Electrical properties of $80 \mathrm{~nm} \mathrm{NiO}$ films deposited with an $\mathrm{Ar}: \mathrm{O}_{2}$ gas flow ratio of 30:70 and thermally annealed at 50,100 , and $200^{\circ} \mathrm{C}$ for $10 \mathrm{~min}$.

Figure 3 shows the transmittance and $E_{g}$ values of $10 \mathrm{~nm}$ thickness $\mathrm{NiO}$ deposited using various $\mathrm{Ar}: \mathrm{O}_{2}$ gas flow ratios (70:30, 50:50, 30:70, and 10:90) at room temperature with thermal annealing at $200^{\circ} \mathrm{C}$ for $10 \mathrm{~min}$. The average transmittance of the $10 \mathrm{~nm} \mathrm{NiO}$ films decreased slightly as $\mathrm{O}_{2}$ gas flow ratios increased, as shown 
in Fig. 3. In addition, the $E_{g}$ values of $\mathrm{NiO}$ films decreased from 3.68 to $3.56 \mathrm{eV}$ as the $\mathrm{O}_{2}$ gas flow ratios increased. The $E_{g}$ values were calculated using the equation $\alpha h \nu=A\left(h \nu-E_{g}\right)^{1 / 2}$, where $A$ is the proportionality constant, $\alpha$ is the absorption coefficient, and $h \nu$ is the photon energy ( $h$ - Plank's constant, $\nu$ - frequency of the photon). The $E_{g}$ values were obtained by extrapolating the linear portion of the curve to zero absorption [11]. Based on the experimental results, we selected the Ar: $\mathrm{O}_{2}$ flow ratio of 30:70 and thermal annealing at $200{ }^{\circ} \mathrm{C}$ for $10 \mathrm{~min}$ at low pressure $\left(10^{-3}\right.$ Torr, $\mathrm{O}_{2}$ gas flow: $100 \mathrm{sccm})$ for the ABL. These conditions were optimal for the resistivity, optical transmittance, and $E_{v}$ level.

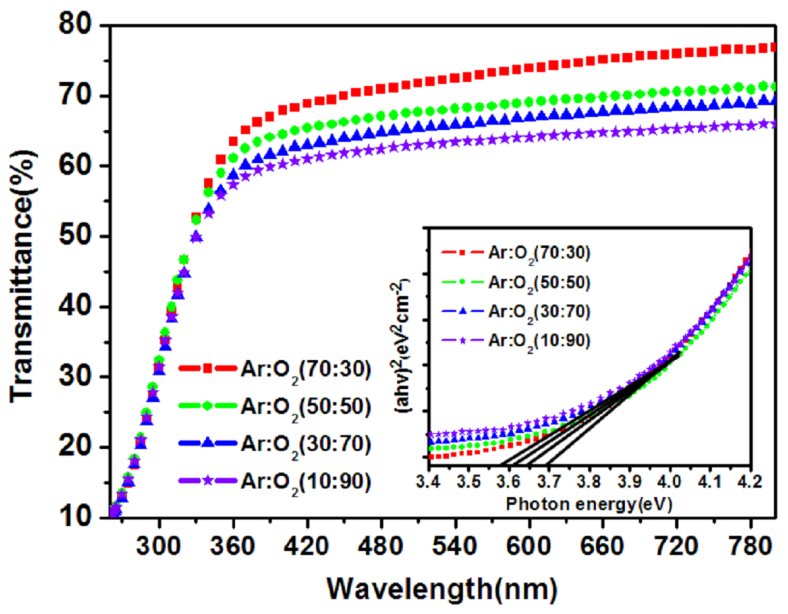

Fig. 3. Optical transmittances and energy band-gaps of $10 \mathrm{~nm}$ thick $\mathrm{NiO}$ deposited using RF magnetron sputtering with various Ar: $\mathrm{O}_{2}$ gas flow ratios (70:30, 50:50, $30: 70$, and 10:90) at room temperature and thermally annealed at $200{ }^{\circ} \mathrm{C}$ for $10 \mathrm{~min}$.

The NiO film obtained at 30:70 had a little lower optical transmittance than deposited with lower $\mathrm{O}_{2}$ gas flow ratios (70:30 and 50:50). Nevertheless, the resistivity and $E_{g}$ value were also lower. When the $E_{v}$ level of the $\mathrm{NiO}$ film is lower than the HOMO energy level of $\mathrm{P}_{3} \mathrm{HT}$, the hole carriers generated in the $\mathrm{P}_{3} \mathrm{HT}$ layer have an energy barrier between the $\mathrm{P}_{3} \mathrm{HT}$ and $\mathrm{NiO}$ ABL. However, when the $E_{v}$ level of the $\mathrm{NiO}$ film approaches the HOMO energy level of $\mathrm{P}_{3} \mathrm{HT}$, the hole carriers are easier to transport from the $\mathrm{P}_{3} \mathrm{HT}$ to the $\mathrm{NiO}$ ABL. This is possible when $E_{g}$ value of the $\mathrm{NiO}$ films decreases as the $\mathrm{O}_{2}$ gas flow ratios increase in the $\mathrm{NiO}$ deposition process.

Figure 4 shows the UPS spectra (He(I) photon energy: $21.2 \mathrm{eV}$ ) of $\mathrm{NiO}$ films deposited with $\mathrm{Ar}_{2} \mathrm{O}_{2}$ flow ratios of 50:50 and of 30:70, and then thermally annealed at $200{ }^{\circ} \mathrm{C}$ for $10 \mathrm{~min}$. The $E_{v}$ level $(-5.1 \mathrm{eV})$ of the $\mathrm{NiO}$ film deposited with a gas flow ratio of 30:70 was higher than that $(-5.3 \mathrm{eV})$ obtained with a ratio of 50:50.

\section{2. $P_{3} H T: P C B M$ BHJ solar cell characterization}

$\mathrm{P}_{3} \mathrm{HT}$ :PCBM BHJ solar cells were fabricated with $\mathrm{NiO}$ ABLs $(5,10$, and $15 \mathrm{~nm})$ deposited with an $\mathrm{Ar}_{2} \mathrm{O}_{2}$ flow
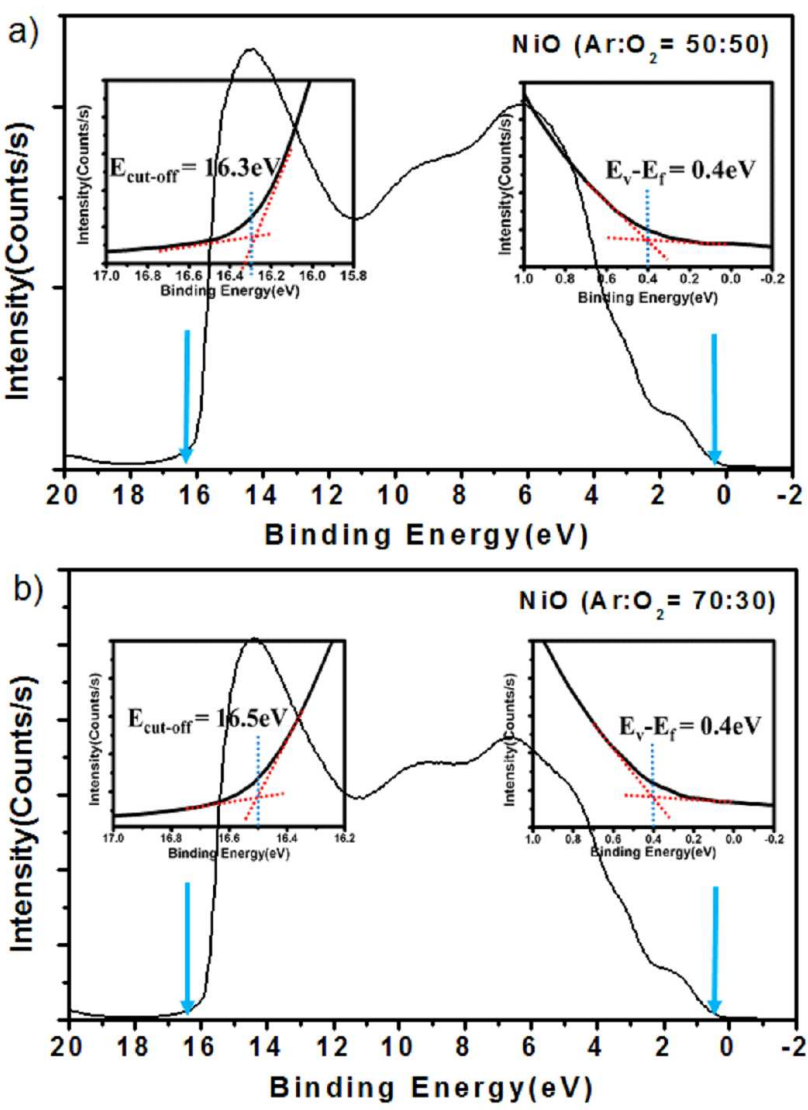

Fig. 4. UPS spectra of NiO films deposited using RF magnetron sputtering with Ar: $\mathrm{O}_{2}$ gas flow ratios of (a) 50:50 and (b) $30: 70$ and thermally annealed at $200^{\circ} \mathrm{C}$ for $10 \mathrm{~min}$.

ratio of 30:70 and thermal annealing at $200^{\circ} \mathrm{C}$ for $10 \mathrm{~min}$. Solar cells were also fabricated using a PEDOT:PSS $p$ type ABL. The process conditions were the same except for the ABL process. Figure 5 shows the current densityvoltage plots of the fabricated solar cells. The electrical parameters of the solar cells are summarized in Table I. For the solar cell fabricated with the PEDOT:PSS ABL, open-circuit voltage $\left(V_{o c}\right)$, short-circuit current density $\left(J_{s c}\right)$, fill factor $(\mathrm{FF})$, and power conversion efficiency (PCE) were $0.69 \mathrm{~V}, 7.3 \mathrm{~mA}, 44 \%$, and $3.03 \%$, respectively. The $V_{o c}, J_{s c}$, and PCE values of the solar cell fabricated with $10 \mathrm{NiO}$ ABL were $0.75 \mathrm{~V}, 14.3 \mathrm{~mA}$, and $4.71 \%$, respectively, which are higher than those obtained with the PEDOT:PSS ABL. Thus, the data indicate that replacing the PEDOT:PSS with the $\mathrm{NiO}$ ABL is feasible. The $J_{s c}\left(14.3 \mathrm{~mA} / \mathrm{cm}^{2}\right)$ value obtained with the $10 \mathrm{~nm}$ $\mathrm{NiO} \mathrm{ABL}$ was much higher than previously reported values $[12,13]$.

The energy levels of the materials used are shown in Fig. 6. $p$-type $\mathrm{NiO}$ is generally known to have a wide band gap, with $E_{f}$ level of $-5 \mathrm{eV}$ and $E_{v}$ level of $5.4 \mathrm{eV}$ [14]. The $E_{v}$ level of $\mathrm{NiO}$ film deposited with an Ar: $\mathrm{O}_{2}$ gas flow ratio of 50:50 was $-5.3 \mathrm{eV}$, while that 
TABLE I

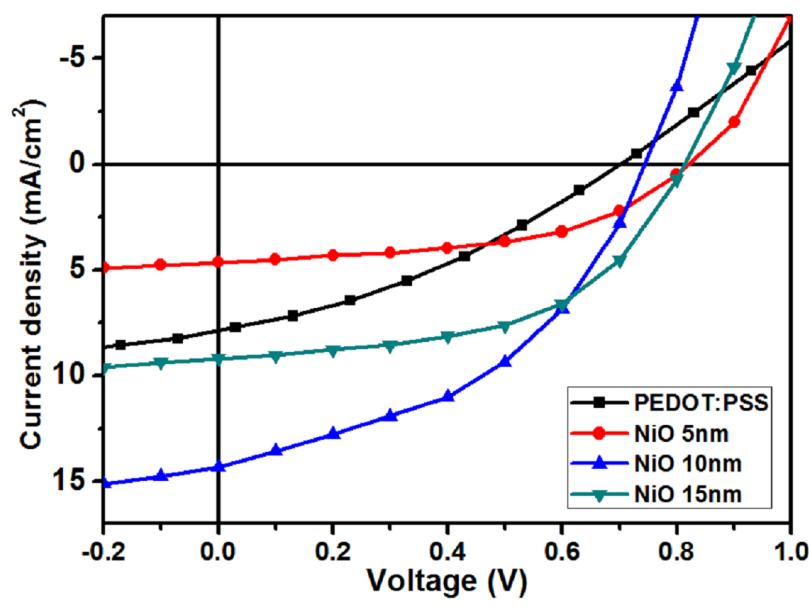

Fig. 5. Current density-voltage plots of $\mathrm{P}_{3} \mathrm{HT}$ :PCBM BHJ solar cells fabricated with 5, 10, and $15 \mathrm{~nm}$ thickness $\mathrm{NiO}$ ABLs deposited using RF magnetron sputtering with an $\mathrm{Ar}: \mathrm{O}_{2}$ gas flow ratio of 30:70 and thermally annealed at $200^{\circ} \mathrm{C}$ for $10 \mathrm{~min}$, as well as PEDOT:PSS $(100 \mathrm{~nm})$ anode buffer layers.

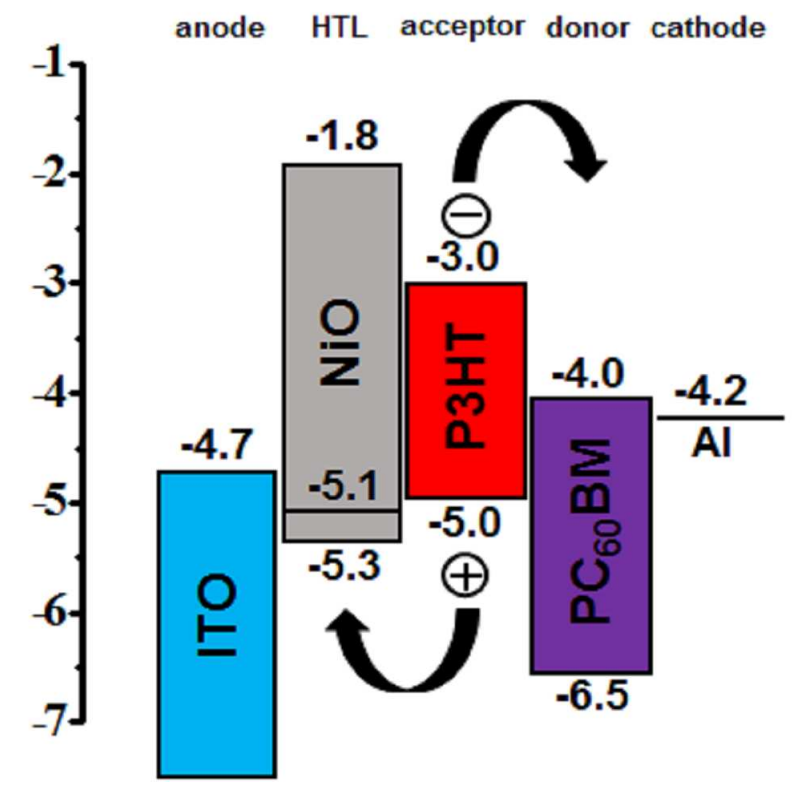

Fig. 6. Energy level diagram of a $\mathrm{P}_{3} \mathrm{HT}$ :PCBM BHJ solar cell with a $\mathrm{NiO}$ anode buffer layer.

obtained at 30:70 was $-5.1 \mathrm{eV}$ as shown in Fig. 4 . The $E_{v}$ levels increased with the $\mathrm{O}_{2}$ flow ratios. The $E_{v}$ level of the $\mathrm{NiO} \mathrm{ABL}$ obtained with a ratio of 30:70 was near the HOMO energy level $\left(\approx 0.1\right.$ below $\left.E_{f}\right)$ of $\mathrm{P}_{3} \mathrm{HT}$, as shown in Fig. 4. When $E_{v}$ level of the $\mathrm{NiO} \mathrm{ABL}$ is close to the HOMO energy level of $\mathrm{P}_{3} \mathrm{HT}$, the holes generated at the HOMO energy level of $\mathrm{P}_{3} \mathrm{HT}$ are transported more easily to the $E_{v}$ of the NiO ABL. The LUMO energy level $(-1.8 \mathrm{eV})$ of $\mathrm{NiO}$ is higher than that of PCBM $(-4.0 \mathrm{eV})$, as shown in Fig. 6 [14]. Thus, the transport of electrons
Electrical parameters of $\mathrm{P}_{3} \mathrm{HT}$ :PCBM BHJ solar cells fabricated with 5,10 , and $15 \mathrm{~nm}$ thickness $\mathrm{NiO}$ ABLs deposited using RF magnetron sputtering with an Ar: $\mathrm{O}_{2}$ gas flow ratio of 30:70 and thermally annealed at $200{ }^{\circ} \mathrm{C}$ for $10 \mathrm{~min}$, as well as PEDOT:PSS (100 nm) anode buffer layers.

\begin{tabular}{c|c|c|c|c|c|c}
\hline \hline $\begin{array}{c}\text { Film } \\
\text { thickness } \\
{[\mathrm{nm}]}\end{array}$ & $\begin{array}{c}V_{O C} \\
{[\mathrm{~V}]}\end{array}$ & $\begin{array}{c}J_{S C} \\
{\left[\frac{\mathrm{mA}}{\mathrm{cm}^{2}}\right]}\end{array}$ & $\begin{array}{c}\mathrm{FF} \\
{[\%]}\end{array}$ & $\begin{array}{c}\mathrm{PCE} \\
{[\%]}\end{array}$ & $\begin{array}{c}R_{S} \\
{[\Omega]}\end{array}$ & $\begin{array}{c}R_{S h} \\
{[\Omega]}\end{array}$ \\
\hline $\begin{array}{c}\text { PEDOT: } \\
\text { PSS (100) }\end{array}$ & 0.69 & 7.3 & 44 & 3.03 & 246 & 2330 \\
\hline $\mathrm{NiO}(5)$ & 0.82 & 4.65 & 50 & 1.90 & 1008 & 420 \\
\hline $\mathrm{NiO}(10)$ & 0.75 & 14.3 & 44 & 4.71 & 388 & 2996 \\
\hline $\mathrm{NiO}(15)$ & 0.82 & 9.18 & 53 & 3.96 & 655 & 17476
\end{tabular}

generated from the PCBM to the ITO electrode would be prevented with the $\mathrm{NiO}$ ABL.

The solar cell fabricated with a $10 \mathrm{~nm} \mathrm{NiO} \mathrm{ABL} \mathrm{had} \mathrm{a}$ much higher $J_{s c}\left(14.3 \mathrm{~mA} / \mathrm{cm}^{2}\right)$ than those of the other samples $4.65 \mathrm{~mA} / \mathrm{cm}^{2}(5 \mathrm{~nm})$ and $9.18 \mathrm{~mA} / \mathrm{cm}^{2}(15 \mathrm{~nm})$. However, FF for the $10 \mathrm{~nm} \mathrm{ABL} \mathrm{(44 \% )} \mathrm{was} \mathrm{lower} \mathrm{than}$ the other samples of $50 \%(5 \mathrm{~nm})$ and $53 \%(15 \mathrm{~nm})$. PCE obtained with the $10 \mathrm{~nm} \mathrm{NiO} \mathrm{ABL} \mathrm{(4.71 \% )} \mathrm{was} \mathrm{higher}$ than those obtained with thickness of $5(1.9 \%)$ and $15 \mathrm{~nm}$ $(3.96 \%)$. When the $\mathrm{NiO}$ film thickness is $5 \mathrm{~nm}$, the layer might not completely cover the ITO substrate. Therefore, the parallel resistance $(420 \Omega)$ was lower for this thickness than for the $10 \mathrm{~nm}(2996 \Omega)$ and $15 \mathrm{~nm} \mathrm{NiO}$ ABLs $(17476 \Omega)$, which fully covered the ITO substrate, as shown in Table I. The PCE is very low when the NiO film thickness is less than $8 \mathrm{~nm}$, which is attributed to the large leakage current and insufficient electron blocking [15]. The PCE of solar cell obtained with the $10 \mathrm{~nm}$ $\mathrm{NiO} A B L$ was higher than that obtained with the $15 \mathrm{~nm}$ $\mathrm{NiO}$ ABL. This was probably due to the difference in series resistance between the $10 \mathrm{~nm}(388 \Omega)$ and $15 \mathrm{~nm}$ $(655 \Omega)$ layers.

\section{Conclusions}

We have investigated $\mathrm{NiO}$ thin films obtained using $\mathrm{RF}$ magnetron sputtering with different gas flow ratios of $\mathrm{Ar}: \mathrm{O}_{2}$ and thermal annealing temperatures to replace PEDOT:PSS ABLs in $\mathrm{P}_{3} \mathrm{HT}$ : PCBM BHJ solar cells. PCE was much improved when using the $1 \mathrm{~nm}$ thickness $\mathrm{NiO}$ ABL (471\%) compared to that obtained using the PEDOT:PSS ABL (3.03\%). For the $10 \mathrm{~nm} \mathrm{NiO} \mathrm{ABL}$ obtained with an gas flow ratio of 30:70 and thermally annealed at $200{ }^{\circ} \mathrm{C}$ for $10 \mathrm{~min}$, the $E_{v}$ level was close to the HOMO energy level $\left(\approx 0.1\right.$ below of $\left.E_{f}\right)$ of $\mathrm{P}_{3} \mathrm{HT}$. Therefore, the holes generated at the HOMO energy level of the $\mathrm{P}_{3} \mathrm{HT}$ would transport easily to $E_{v}$ of the $\mathrm{NiO}$ ABL. These results show that the NiO ABL could replace the PEDOT:PSS ABL in $\mathrm{P}_{3} \mathrm{HT}$ : PCBM BHJ solar cells. 


\section{References}

[1] H.-L. Yip, S.K. Hau, N.S. Baek, A.K.-Y. Jen, Appl. Phys. Lett. 92, 193313-1 (2008).

[2] B.C. Thompson, J.M.J. Frechet, Chem. Int. Ed. 47, 58 (2008)

[3] H.-K. Park, J.-W. Kang, S.-I. Na, D.-Y. Kim, H.K. Kim, Sol. Energy Mater. Sol. Cells 93, 1994 (2009).

[4] F.C. Krebs, T. Tromholt, M. Jorgensen, Nanoscale 2, 873 (2010).

[5] K. Kawano, R. Pacios, D. Poplavskyy, J. Nelson, D.D.C. Bradley, J.R. Durrant, Sol. Energy Mater. Sol. Cells 90, 3520 (2000).

[6] V. Shrotriya, G. Li, Y. Yao, C-W. Chu, Y. Yang, Appl. Phys. Lett. 88, 073508 (2006).

[7] M.S. White, D.C. Olson, S.E. Shaheen, N. Kopidakis, D.S. Ginley, Appl. Phys. Lett. 89, 143517 (2006).

[8] K.X. Steirer, J.P. Chesin, N.E. Widjonarko, J.J. Berry, A. Miedaner, D.S. Ginley, D.C. Olson, Org. Electr. 11, 1414 (2010).
[9] K. Ellmer, J. Phys. D Appl. Phys. 33, R17 (2000).

[10] S. Seo, M.J. Lee, D.H. Seo, E.J. Jeoung, D. S. Suh, Y.S. Joung, I.K. Yoo, I.R. Hwang, S.H. Kim, I.S. Byun, J.-S. Choi, B.H. Park, Appl. Phys. Lett. 85, 5655 (2004).

[11] J. Tauc, R. Grigorovici, A. Vancu, Phys. Status Solidi B 15, 627 (1966).

[12] R. Betancur, M. Maymo, X. Elias, L.T. Vuong, J. Martorell, Sol. Energy Mater. Sol. Cells 95, 735 (2011).

[13] D.T. Nguyen, A. Ferrec, J. Keraudy, J.C. Bernede, N. Stephant, L. Cattin, P.-Y. Jouan, Appl. Surf. Sci. 311, 110 (2014)

[14] N. Sun, G. Fang, P. Qin, Q. Zheng, M. Wang, X. Fan, F. Cheng, J. Wan, X. Zhao, Sol. Energy Mater. Sol. Cells 94, 2328 (2010).

[15] N. Sun, G. Fang, P. Qin, Q. Zheng, M. Wang, X. Fan, F. Cheng, J. Wan, X. Zhao, Sol. Energy Mater. Sol. Cells 94, 2328 (2010). 